\title{
PENGETAHUAN ARKEOLOGI SEBAGAI MUATAN LOKAL: PENERAPANNYA DI MALUKU
}

\author{
Archaeological Knowledge as the Local Content: \\ Implementation in Moluccas
}

\author{
Marlon Ririmasse \\ Balai Arkeologi Ambon \\ J1. Namalatu-Latuhalat Ambon 97118 \\ Email: ririmasse@yahoo.com
}

Naskah diterima : 04-03-2014 ; direvisi : 15-04-2014 ; disetujui : 09-05-2014

\begin{abstract}
Diversity is essentially an element that unites Indonesia. The broad geographical character of the region and the complexity of its cultural profile has established a nation with such a colorful appearance. An ability to manage this major diversity has become an absolute requirement as a country. The sensitivity to identify any specific needs of each element of the nation would always be an aspect that must be reviewed and reshaped periodically. Which is also included the need in the education sphere. Local content may be considered as a national solution to answer the breadth dimension of necessity in the school level for the teaching materials that linked with the local characteristics. Connected to this aspect is the interest to provide the knowledge of local culture. Archaeology is a discipline that adequate to share this strategic role for public. This article tries to discuss the contribution of the archaeological study in the development of local content in Moluccas. Literature study have been chosen as an approach to collect data. This study found that archaeology is potential to be developed as a part of local content material in Moluccas.
\end{abstract}

Keywords: Local Content, Archaeology, Moluccas.

\begin{abstract}
Abstrak
Keberagaman sejatinya adalah elemen yang menyatukan Indonesia. Bentang luas geografis dan wajah kompleks budaya nusantara telah membentuk suatu bangsa dengan warna yang begitu raya. Maka kemampuan untuk mengelola kebhinekaan menjadi syarat mutlak yang harus dimiliki sebagai negara. Kepekaan untuk menemukenali kebutuhan-kebutuhan spesifik setiap elemen bangsa kiranya menjadi aspek yang senantiasa harus ditinjau dan dibentuk kembali. Termasuk kebutuhan dalam ranah pendidikan. Muatan lokal pada hakekatnya merupakan solusi nasional dalam menjawab luasnya dimensi kebutuhan di tingkat sekolah akan materi yang bertautan dengan karakteristik daerah. Melekat dalam hal ini adalah kebutuhan untuk menyajikan pengetahuan budaya lokal. Arkeologi juga menjadi bidang yang dituntut berbagi peran dimaksud. Tulisan ini mencoba untuk mendiskusikan kontribusi studi arkeologi dalam pengembangan muatan lokal di Maluku. Studi pustaka dipilih sebagai pendekatan dalam pengumpulan data. Kajian ini menemukan bahwa arkeologi dan pengetahuan sejarah budaya potensial untuk dikembangkan sebagai bagian dari materi muatan lokal di Maluku.
\end{abstract}

Kata Kunci: Muatan Lokal, Arkeologi, Maluku 


\section{PENDAHULUAN}

Ada pengalaman menarik ketika Balai Arkeologi Ambon melakukan sosialisasi hasi penelitian setahun silam. Dalam kegiatan rutin bertajuk archaeology goes to school itu kami mengunjungi salah satu sekolah menengah atas di Kota Ambon. Memula presentasi, foto candi Borobudur ditayangkan sembari bertanya kepada para siswa apakah ada yang mengetahui gambar apa gerangan Serempak hampir seluruh siswa dengan antusias menyebut nama candi terbesa di Indonesia itu. Kami kemudian kembal menampilkan gambar lain. Kali ini adalah foto salah satu benteng kolonial yang berada dalam radius kurang lebih satu kilometer dari sekolah tersebut. Letaknya memang agak tersembunyi di luar kawasan hunian namun tetap cukup dikenal. Meski demikian saat ditanya kepada siswa apakah ada yang mengetahui bangunan apa ini, tidak terdengar lagi suara antusias. Semua siswa terliha berpikir bangun berpikir bangunan apa yang ditunjukan di dalam gambar. Tak ada yang mengetahu nama benteng yang ditampilkan. Padaha jaraknya relatif dekat. Situasi serupa terlihat ketika dokumentasi beberapa objek lain yan telah cukup dikenal sebagai ikon budaya di Maluku ditayangkan. Tak banyak yang tahu. Hanya segelintir siswa yang menjawab. Itupun dengan sedikit menerka.

Kondisi ini memang sering dijumpa dalam setiap kesempatan kegiatan sosialisas arkeologi di sekolah-sekolah di Maluku selama enam tahun terakhir. Kecenderungannya serupa. Siswa lebih mengenal dan memahami objek-objek yang menjadi ikon sejarahbudaya nasional. Sementara pengetahuan terkait warisan budaya lokal sangat minimal. Padahal objek-objek lokal yang ditampilkan seringkali sudah cukup dikenal dan terjangkau dalam keseharian para siswa. Dalam konteks yang lebih luas situasi serupa juga ditemukan terkait pengetahuan sejarah lokal spesifik seperti sejarah kota. Siswa cenderung tidak mengetahui latar historis kota mereka.

Kesenjangan pengetahuan terkait sejarah-budaya nasional dan sejarah budaya- lokal memang menjadi fenomena yang agaknya umum ditemui di berbagai daerah $\mathrm{d}$ Indonesia. Sebuah kondisi yang merupakan konsekuensi mengelola negara luas dengan keberagaman tinggi. Di satu sisi, dunia pendidikan dituntut untuk mampu menyajikan kurikulum dan materi yang merepresentasikan Indonesia sebagai sebuah entitas wilayah. Di sisi lain, kondisi negara yang semakin terbuka melahirkan kebutuhan akan tema spesifik yang selaras dengan kondisi daerah Penerapan muatan lokal sebagai bagian dari kurikulum merupakan solusi untuk menjawab kebutuhan khusus dimaksud. Dengan konten yang direka dari sumber-sumber lokal untuk diolah dan disajikan sebagai pengetahuan terkait kondisi setempat, bahan ajar ini dirasa sejalan dengan upaya meningkatkan kepekaan siswa akan kondisi dan potensi daerahnya.

Meski demikian, konsep muatan

lokal dalam bahasa diibaratkan sebagai gagasan jitu yang dalam kenyataan belum dapat ditanggulangi oleh kalangan pendidik sendiri (Sedyawati, 2007a: 5). Gagasan keseimbangan yang ditawarkan muatan lokal seringkali terbentur oleh keterbatasan ketersediaan bahan ajar dan tenaga pengajar dengan pengetahuan spesifik. Pengalaman dari kegiatan sosialisasi arkeologi di atas barangkali merupakan salah satu cermin kendala tersebut di tingkat sekolah. Solusi untuk mengatasi kesenjangan itu dapat diupayakan untuk ditanggulangi dengan 'melegalkan' penggunaan tenaga-tenaga non-guru dalam masyarakat yang memiliki pengetahuan dan keahlian mengenai berbaga aspek kehidupan yang khas bagi wilayah tertentu (Sedyawati, Ibid). Dalam konteks pengetahuan sejarah budaya, melibatkan pihak-pihak yang aktif bergiat dalam kajian arkeologi kiranya merupakan salah satu solusi. Tulisan ini mencoba untuk meninjau kontribusi studi arkeologi dalam mengembangkan pengetahuan terkait muatan lokal di Maluku.

Keberadaan pengetahuan sejarahbudaya lokal kini dirasa semakin dibutuhkan untuk melengkapi konten-konten sejarah nasional. Karakter khas latar historis entu memerlukan materi dan pendekatan selaras dengan kebutuhan spesifik setempat. Muatan lokal kiranya merupakan salah satu solusi bagi kondisi dimaksud dengan menghadirkan pihak-pihak non-guru yang memiliki pengetahuan dan keahlian spesifik terkait daerah. Arkeologi kiranya merupakan salah satu ranah yang dapat ditinjau untuk memberikan kontribusi. Mengacu pada situasi dimaksud makalah ini mencoba meninjau satu masalah pokok: bagaimanakah penerapan arkeologi sebagai muatan lokal di Provinsi Maluku?

\section{METODE}

Sejalan dengan gagasan kajian ini yang mencoba mengamati secara konseptual peran arkelogi sebagai muatan lokal dalam pendidikan, maka pendekatan yang digunakan dalam tulisan ini adalah kajian pustaka. Referensi utama yang menjadi rujukan adalah segenap sumber-sumber terkait hasil penelitian arkeologis yang dipandang memiliki relevansi untuk diakomodasi sebagai muatan lokal. Demikian halnya dengan rujukan berupa laporan kegiatan pemasyarakatan Balai Arkeologi Ambon yang telah dilakukan dan ditujukan untuk memperluas pengetahuan masyarakat tentang arkeologi Maluku selama ini. Rujukan pustaka juga akan merangkul pengetahuan terkait gagasan muatan lokal dalam pendidikan nasional dan di Maluku.

\section{HASIL DAN PEMBAHASAN}

Arkeologi dan Publik: Pergeseran Paradigma

Pengetahuan masyarakat terkait apa itu arkeologi senantiasa beragam. Walaupun secara umum cukup memahami bahwa arkeologi adalah ilmu yang terkait dengan pengetahuan tentang masa lalu. Begitu melekatnya citra ini, sehingga sering ditemui bahwa segala sesuatu yang berasal dari masa silam dipandang senantiasa memiliki hubungan dengan arkeologi. Padahal tidak demikian. Meski senantiasa bekerja lintas keilmuan, arkeologi adalah bidang kajian spesifik yang berfokus pada upaya untuk alu beserta segala aspek yang melingkupinya. Meliputi aspek sosial, ekonomi, politik, lingkungan hingga teknologi.

Sebagai sebuah bidang ilmu arkeolog umbuh dari minat individu atas benda-bend antik dan langka. Hasrat ini senantiasa melekat dengan keingintahuan untuk menjelaskan misteri dibalik keberadaan objek-objek khas tersebut disertai semangat petualangan $\mathrm{di}$ lingkungan budaya asing. Berangsur-angsu aktivitas ini ditata dan berkembang menjad sebuah bidang kajian dengan kaidah-kaidah yang sejalan dengan norma-norma ilmiah. Metode dan teknik disempurnakan seringkali dengan mengadopsi model serupa dan bidang lain. Tak mengherankan bila saat ini prinsipprinsip kerja dalam kajian arkeologis telah menjadi sedemikian terukur dan presisi.

Aktivitasnya yang begitu bertautan engan penelitian seringkali membuat pergerakan arkeologi sebagai ilmu dominan berada dalam ranah akademis. Dimana segenap pengetahuan yang diperoleh dari hasil studi cenderung berada dalam siklus internal arkeologi dan ilmu-ilmu sejawatnya. Situasi ini sejatinya sahih dalam dunia sains Apalagi ranah akademis sebagai ruang diskusi yang dinamis identik dengan respon kritis yang penting bagi retrospeksi hasil-hasi kajian arkeologis. Meski di satu sisi positif, bagi sebagian kalangan dalam arkeologi, situasi dengan ruang terbatas ini dirasa membuat arkeologi menjadi displin yang eksklusif (Prasodjo, 2002).

Otokritik ini kiranya merupakan implikasi dari pergeseran pemikiran yang meluas dalam arkeologi. Munculnya arus pemikiran baru dalam lingkup luas keilmuan seperti posmodernisme, berimbas juga pada aku arkeologi sebagai ilmu (Tanudirdjo, 1996). Situasi dunia yang kian berubah kiranya menjadi pemicu lain pergeseran pemikiran ni. Kemudahan informasi dan komunikas membuat masyarakat global semakin terbuka dan terhubungkan satu sama lain. Implikas dari kondisi ini adalah semakin mudahnya 
nilai-nilai dan pengetahuan baru mengalir melintasi batas-batas negara. Perubahan ini kiranya juga bermuara pada cara pandang masyarakat terhadap pengetahuan masa lalu beserta segenap warisan materinya. David Lowenthal (1981), ahli konservasi bereputas dunia menulis .. "...the past belongs to everyone; the need to return home, to recall the view, to refresh a memory, to retrace a heritage, is universal and essential..." (Lowenthal, 1981)

Pengetahuan masa lalu beserta segenap warisan budayanya dimana saja, sejatinya merupakan milik seluruh uma manusia. Dengan demikian tanggung jawab atas kelestarian dan pengelolaannya menjad kewajiban bersama. Pergeseran pemikiran ini kiranya juga tidak lepas dari tumbuhnya kesadaran baru dalam lingkup arkeolog mulai sekitar dua dekade silam, bahwa pembiayaan segenap aktivitas penelitian yang dilaksanakan bersumber dari pajak yang dibayarkan oleh masyarakat. Karen itu arkeologi memiliki tanggung jawab untuk mengembalikan segenap hasil-hasil kajiannya bagi masyarakat luas. Masyarakat tidak lagi dipandang sebagai pihak luar, namun dipahami sebagai pemilik sejati sumbe daya budaya yang menjadi perhatian studi arkeologi (Schofield, 2007; Jameson, 2000). Berkiblat pada pergeseran pemikiran ini, maka menurut Tanudirdjo (2003), arkeologi mesti mereposisi dirinya. Arkeologi tidak bisa lagi berdiri sebagai legislator namun harus menempatkan diri sebaga mediator. Kiblat arkeologi yang selama in berpijak pada negara dan berfungsi sebagai penjaga mestilah ditinjau kembali denga hadir sebagai pelayan bagi masyarakat (Tanudirdjo, 2003; Kohldan Fawcett, 1995). (Tanudirjo, 2003; Kohl ban Fawcet, 1995). adalah arkeologi harus memiliki kepekaan untuk mengetahui kepentingan yang ad di masyarakat terkait segenap sumber daya budaya dan pengetahuan masa lalu. Kemampuan untuk menemukenali kebutuhan masyarakat yang beragam inilah yang akan membuat arkeologi mampu memberikan kontribusi maksimal bagi masyarakat.
Muatan Lokal: Kebhinekaan sebagai

\section{Karakter Nasional}

Gelombang perubahan paradigma yang melekat dengan prinsip-prinsip keterbukaan agaknya juga menjadi fenomen yang terjadi di Indonesia mulai hampir dua dekade silam. Kelonggaran informasi pada taraf global telah menciptakan kemudahan akses pada pengetahuan dan bentuk-bentuk pemikiran baru yang selama ini nyaris tidak terjangkau. Tidak mengherankan gagasangagasan baru yang lekat dengan kesetaraan menerima keberagaman dan merangku kepentingan minoritas juga bertumbuh $\mathrm{d}$ Indonesia. Diinisiasi oleh perubahan sistem politik dari sentralistik menjadi otonomi, proses transformasi ini juga berlanjut ke dunia pendidikan (Bjork, 2004).

Muatan lokal merupakan wujud dar upaya transformasi dimaksud. Karakter kurikulum yang selama ini sudah diupayakan untuk mewakili keberagaman Indonesia, dirasa belum memberikan ruang yang maksimal bagi kebutuhan pengetahuan spesifik di daerah. Wawasan peserta didik seringkali luas dalam pemahaman tematema yang bersifat nasional, namun minima dalam pengetahuan lokal. Kehadiran mater ajar yang bersifat lokal dirasa dapat menjadi solusi bagi kondisi dimaksud.

Pengembangan muatan lokal sendir sejak lebih dari satu dekade silam didorong oleh setidaknya lima faktor yaitu: (1). Pelaksanaan Otonomi Daerah (2) Desentralisasi (3) Karakter khas Indonesia yang bersifa multikultur (4) perlunya perluasan wawasan peserta didik terkait kekhususan pada lingkungannya (5) kebutuhan akan pengembangan kurikulum yang mengacu pada karakteristik sosial budaya setempat dan menunjang kelestariannya. Kondisi khas dan karakter spesifik daerah memang merupakan rujukan utama mengapa pengembangan muatan lokal ditetapkan dengan dasar hukum yang bersesuaian meliputi: (1) UU No. 32 tahun 2004 tentang Pemerintahan Daerah, (2)Undang-Undang Nomor 20 Tahun 2003 tentang Sisdiknas Pasal 37 ayat (1) dan pasal
38 ayat (2), (3) Permen RI Nomor 19 tahun 2005 tentang Standar Nasional Pendidikan, (4) Perda Kabupaten atau Kota.

Dengan latar pemikiran sebagaimana disebutkan di atas maka tujuan muatan lokal senantiasa melekat pada upaya untuk memberikan pengetahuan dan meluaskan wawasan terkait lingkungan dan budaya setempat kepada peserta didik. Termasuk dalam tujuan tersebut adalahtarget agar para peserta didik dapat: (a) Mengenal dan menjadi lebih akrab dengan lingkungan alam, sosial, dan budayanya (b) Memiliki bekal kemampuan dan keterampilan serta pengetahuan mengenai daerahnya yang berguna bagi dirinya maupun lingkungan masyarakat pada umumnya (c) Memiliki sikap dan perilaku yang selaras dengan nilainilai/aturan-aturan yang berlaku di daerahnya, serta melestarikan dan mengembangkan nilainilai luhur budaya setempat dalam rangka menunjang pembangunan nasional.

Setelah dilaksanakan lebih dari satu dekade, penerapan muatan lokal di berbagai daerah dan sekolah menunjukan hasil yang bervariasi. Beberapa wilayah mampu mengakomodasi aspek-aspek khas setempat sebagai kontenmuatan lokal. Ada yang melangkah lebih jauh dengan keberhasilan mengemas tema-tema terkait budaya sebagai materi. Meski demikian, sebagian besar daerah agaknya masih mennyajikan subjeksubjek yang lebih umum untuk mengisi ruang muatan lokal di sekolah. Menurut pandangan Sedyawati (2007), perbedaan keberhasilan penerapan muatan lokal ini terkait erat dengan kesediaan bahan ajar dan kesiapan kalangan pendidik untuk subjek spesifik ini (Sedyawati, 2007b). Untuk itu dunia pendidikan dirasa perlu merangkul tenagatenaga non-guru dalam masyarakat yang memiliki pengetahuan dan keahlian yang khas mengenai berbagai aspek kehidupan yang khas pula bagi wilayah tertentu (Sedyawati, Ibid). Menimbang pengetahuan budaya merupakan salah satu aspek yang dikelola dalam pelaksanaan muatan lokal, melibatkan para penggiat di bidang ini kiranya dapat menjadi solusi, yaitu dengan membuka ruang bagi para antropolog, sejarawan hingg seniman tradisional.

Luasnya ranah pengetahuan budaya ini sendiri kiranya dapat dipertajam dengan membentuk segmen-segmen tematis yang disajikan secara parsial dalam muatan lokal. Tema sejarah lokal dan pengetahuan terkait warisan budaya dapat menjadi ranah potensial bagi arkeologi untuk memberikan kontribusinya bagi pengembangan muatan lokal. Representasi arkeologi dalam konten sejarah nasional yang umumnya diwakili oleh tema-tema nasional dengan situs dan objekobjek ikonik, dapat disandingkan dengan pengetahuan arkeologis setempat melalui muatan lokal. Melalui model ini, benang merah sejarah budaya di Nusantara yang sejatinya saling bertautan antar wilayah dapa dipahami dengan lebih selaras. Keberadaan pengetahuan warisan budaya di sekolah juga kan membantu upaya pelestarian karena sejak dini generasi muda sebagai pemangku kepentingan telah dibentuk kepekaannya atas pusaka budaya setempat.

\section{Pengetahuan Arkeologi sebagai Muatan}

\section{Lokal: Penerapannya di Maluku}

Sebagaimana halnya wilayah lain

di Indonesia, Maluku adalah daerah dengan karakter yang khas. Dibentuk oleh lebih dari seribu buah pulau dengan wilayah lautan yang dominan mencapai lebih dari sembilan puluh persen luas wilayah, Maluku dapat dipandang sebagai miniatur Indonesia (Ririmasse, 2010). Profil geografis yang sedemikian menyebar membuat kemampuan mengelola pendidikan secara merata senantiasa menjad tantangan di wilayah ini. Jumlah tenaga guru dan kesediaan materi ajar yang memada dalam kuantitas dan kualitas menjadi aspek yang terus dibenahi. Karakter geografis yang khas ini juga yang membuat pengembangan muatan lokal sebagai bahan ajar di sekolah menjadi tantangan tersendiri bagi wilayah ini.

Pengalaman saat melakukan kegiatan osialisasi di sekolah menunjukan hampir seluruh sekolah menengah tingkat atas 
di Kota Ambon memilih Bahasa Inggris sebagai materi muatan lokal. Materi terkait sejarah budaya Maluku sama sekali belum diakomodasi sebagai muatan lokal. Melalu diskusi dengan para guru terungkap bahwa ketersediaan bahan ajar merupakan kendal utama. Itulah mengapa meski memiliki tenaga pendidik dengan spesialisasi yang bersentuhan dengan budaya seperti sejarah dan kesenian, tema-tema lokal tetap belum bisa diangkat sebagai muatan lokal. Ruangruang kosong ini yang sewajarnya diisi oleh individu pun institusi yang aktivitasnya bersentuhan dengan budaya Maluku secara umum.

Balai Arkeologi Ambon adalah salah satu institusi yang mencoba mengis ruang kosong dimaksud. Hadir sebagai Uni Pelaksana Teknis di bawah Kementerian Pendidikan dan Kebudayaan, tugas dan fungs insititusi ini adalah melakukan kegiatan penelitian dan pemasyarakatan arkeologi di wilayah Maluku dan Maluku Utara. Berdiri sejak tahun 1996, Balai Arkeologi Ambon telah melakukan penelitian di hampir seluruh pelosok kepulauan luas ini (Ririmasse 2005). Kedalaman kajian tentu bervariasi. Menimbang luasnya wilayah kerja, sifat penelitian umumnya diarahkan untuk proses eksplorasi, dokumentasi dan registrasi. Kajian yang lebih dalam tentu saja dilakukan pada situs-situs yang dipandang potensial. Segenap hasil penelitian ini juga diteruskan kepada masyarakat luas. Baik di Maluku maupun Indonesia. Salurannya beragam. Mula dari penerbitan rutin jurnal ilmiah, akses luas lewat website, pelaksanaan pameran arkeologi rutin, hingga rangkaian kegiatan sosialisasi dengan sasaran utama sekolahsekolah di Maluku.

Archaeology goes to School adalah label yang dipilih untuk rangkaian kegiatan sosialisasi rutin yang dilakukan oleh Bala Arkeologi Ambon. Mulai berjalan sejak tahun 2006, kini kegiatan kunjungan ke sekolah-sekolah ini biasanya dilakukan dengan fruekuensi enam hingga delapa kali per tahun. Umumnya sekolah yang menjadi tujuan utama adalah setingkat SMU dan Sederajat. Terdapat juga kunjungan untuk sekolah setingkat SMP namun dalam jumlah terbatas. Lokus sosialisasi diarahkan agar merata. Tidak hanya dilakukan di Kota Ambon, namun meluas ke kota-kota kabupaten lainnya. Meski terbatas, kegiatan sosialisasi juga dilakukan di beberapa situs pilihan yang pada saat yang sama menjadi lokasi penelitian.

Materi yang disajikan bersifat komposit. Saling melengkapi. Biasanya diawali dengan presentasi pengenalan apa itu studi arkeologi kepada siswa dan dilanjutkan dengan presentasi tema-tema spesifik terkait hasil-hasil penelitian di wilayah Maluku dan Maluku Utara. Pengenalan arkeologi biasanya diarahkan pada presentasi karakter khas studi arkeologi beserta objek penelitian, metode dan teknik yang digunakan untuk mendapatkan data. Bagaimana segenap pengetahuan arkeologi ini dikelola untuk kepentingan yang lebih luas juga senantiasa dijelaskan. Salah satunya adalah mengelola pengetahuan arkeologi untuk tujuan pendidikan itu sendiri. Ikon-ikon populer yang melekat dengan tema arkeologi sering ditampilkan untuk mempermudah asosiasi siswa terhadap bidang kajian ini. Terkait hasil penelitian biasanya ditampilkan secara tematis: meliputi tema prasejarah, Hindu Budha, Islam dan Kolonial. Bukti-bukti budaya dari berbagai masa berbeda ini selintas disajikan dalam kerangka sejarah dan arkeologi nasional sebelum digiring dan dikaitkan dengan jejak budaya semasa yang ada di Kepulauan Maluku.

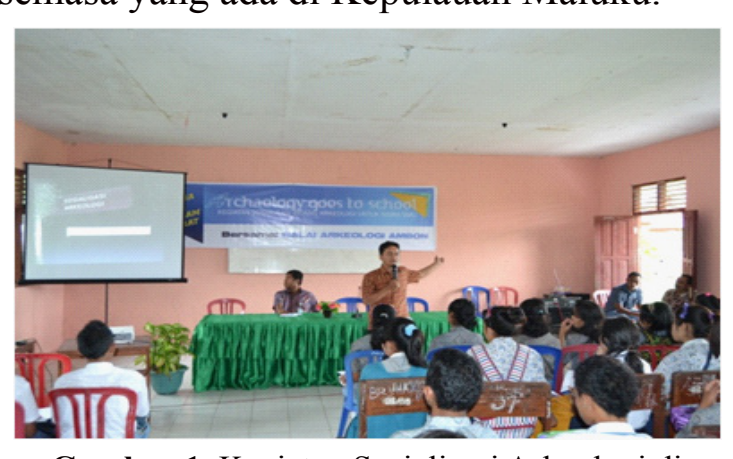

Gambar 1. Kegiatan Sosialisasi Arkeologi di Sekolah oleh Balai Arkeologi Ambon

(Sumber: Dokumen Balai Arkeologi Ambon)
Spesifikasi tema juga senantiasa diarahkan bersesuaian dengan lokus kegiatan sosialisasi. Jika kegiatan sosialisasi dilakukan di Kota Ambon, maka isu-isu terkait sejarah di Kota Ambon, maka isu-isu terkait sejarah perkembangan kota beserta yang menyertainya selalu ditampilkan. Dokumentasi kuno terkait lingkungan sekitar sekolah dalam konteks tata ruang kota juga disajikan. Jika kegiatan dilakukan di kotakota kabupaten atau kecamatan, maka hasil kota kabupaten atau kecamatan, maka hasil penelitian dan karakter potensi arkeologis di
wilayah-wilayah spesifik ini yang ditampilkan dan ditautkan dalam konteks Maluku dan Nasional. Khusus untuk kegiatan yang dilakukan dalam konteks penen lapangan, sosialisasi dilakukan bukan saja di sekolah, namun juga dengan memberikan kesempatan bagi siswa untuk berkunjung ke situs dan melihat secara langsung proses penelitian arkeologis. Di sini hasil-hasil penelitian berupa temuan hasil ekskavasi dipamerkan dan siswa dapat berinteraksi dengan para peneliti secara langsung.

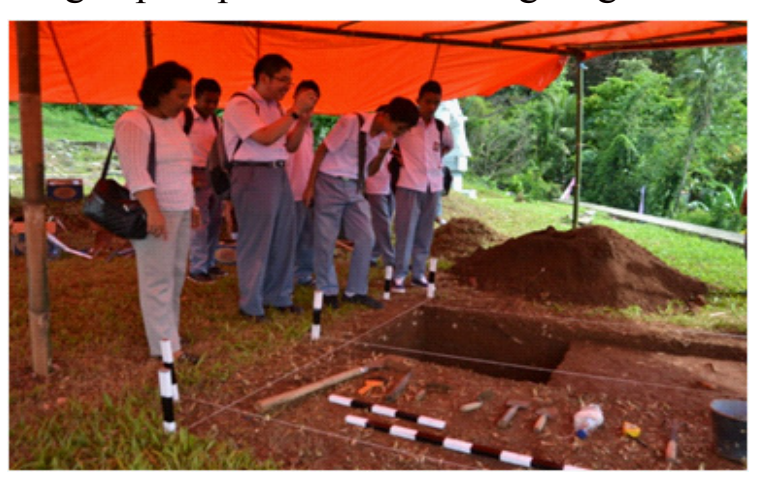

Gambar 2. Simulasi Ekskavasi Bagi Siswa SMU

(Sumber: Dokumen Balai Arkeologi Ambon)

Sejauh ini respon yang diberikan oleh siswa dan pihak sekolah di Maluku senantiasa positif. Kehadiran arkeologi sebagai bidang yang spesifik dan tidak umum ditemui, biasanya menjadi faktor penarik utama. Kalangan pendidik biasanya sangat antusias karena senantiasa terkait dengan materi yang disajikan merupakan kontenkonten lokal yang selama ini tidak ditemukan dalam referensi umum di Maluku. Kehadiran kegiatan sosialisasi arkeologi ini senantiasa dipandang sebagai media pembelajaran sejarah lokal yang selama ini hampir tidak pernah ada salurannya di sekolah. Beragam masukan juga diterima. Umumnya terkait dengan permintaan agar frekuensi kegiatan sosialisasi bisa ditingkatkan dan durasinyapun diperlonggar. Saran juga disampaikan agar publikasi-publikasi yang selaras dengan daya cerna siswa juga diperbanyak untuk mempermudah akses siswa pada pengetahuan sejarah budaya setempat.

Diskusi: Meningkatkan Mut Kegiatan Sosialisasi Arkeologi untu Mengembangkan Muatan Lokal

Setelah dilaksanakan selama enam tahun, kegiatan archaeology goes to school ini senantiasa diupayakan untuk ditingkatkan kualitasnya. Upaya diarahkan untuk memberikan kemudahan bagi siswa guna memahami arkeologi dan pengetahuan sejara budaya dalam konteks lokal di Maluku. Berpijak pada berbagai masukan yang diterima selama kurun waktu di atas maka perhatian untuk pengembangan diarahkan pada setidaknya lima aspek meliputi: pertama pengembangan tema konten kedua, inisias model sosialisasi yang lebih interaktif ketiga pembaharuan materi keempat, peningkata frekuensi kelima, pembinaan tenaga guru.

Pertama, pengembangan konte kegiatan sosialisasi arkeologi di Balai Arkeologi Ambon dimaksudkan agar materi spesifik ini lebih mudah dicerna oleh para siswa. Untuk itu salah satu solusi adalah dengan menautkan pengetahuan spesifik in dengan konten mata-mata pelajaran tertentu di sekolah. Selain sejarah,mata pelajaran sepert geografi, fisika, biologi, matematika hingg pendidikan budi pekerti dapat diakomodasi. Mata pelajaran sejarah kiranya senantiasa selaras dengan materi sosialisasi. Penyesuaian dapat dilakukan dengan menyajikan buktibukti budaya lokal yang berkorelasi dengan tema-tema besar dalam buku ajar sejarah nasional. Tema prasejarah dapat mengaitkan bukti-bukti budaya paleolitik hingga neolitik di Indonesia dengan bukti-bukti serupa di Maluku. Jejak budaya logam menjelang akhir budaya prasejarah ditemukan luas di wilayah 
selatan Maluku. Fenomena ini kiranya dapa dikaitkan dengan sebaran serupa dalam lingkup geografis Asia Tenggara, Daratan Sumatera, Jawa hingga Sunda Kecil. Jejak budaya Hindu Budha yang selama ini dipandang tidak ditemukan di sebelah timur Nusantara, ternyata teridentifikasi di Kepulauan kei dan Maluku Utara. Bukti-bukti masuk dan berkembangnya pengaruh Islam diwakil oleh luasnya tinggalan masa ini di berbagai onteks tinggala maluku sebaga pusat rempah-rempah, membuat wilayah in memiliki sebaran benteng paling banyak di Nusantara (Ririmasse, 2005). Geograf dapat dikaitkan dengan karakteristik budaya di tiap wilayah di Maluku atau menjelaska mengenai kondisi geografi purba di Maluku. Biologi dapat dikaitkan dengan karakter khas Maluku sebagai bagian dari zona transisi Wallasea dan bagaimana lingkungan khas ini berpengaruh bagi perkembangan buday di wilayah ini (Ririmasse, 2011). Termasuk karakteristik tanaman endemik cengkeh dan pala yang berkembang sebagai komoditi penting mulai dua millonnium silam. Budi pekerti dapat pekerti dapat dikaitkan dengan nilai-nila filosofis setempat yang terkandung dalam objek-objek arkeologis yang ada di Maluku. Objek seperti dolmen, monumen tradisiona dan rekayasa ruang tradisional senantiasa melekat dengan nilai-nilai kebersamaan. Kompleksitas warisan budaya di Maluku senantiasa mewakili tema-tema keberagaman yang dapat disajikan bagi siswa (Ririmasse, 2008).

Kedua, pengembangan mode sosialisasi yang lebih interaktif kirany juga merupakan tantangan. Selama in pendekatan sosialisasi lebih banyak dilakukan di dalam ruang kelas melalui model tatap muka. Pelibatan siswa dalam kunjungan ke lokus penelitian juga dilakukan namun bersifat terbatas. Dalam aspek kedua ini, pengembangan dapat dilakukan antara lain dengan meningkatkan frekuensi kunjungan ke situs-situs arkeologi agar pengalaman nyata siswa dalam kajian khas ini dapat dialami. Simulasi ekskavasi (penggalian arkeologis) juga dapat dilakukan baik di lapangan maupun di lokasi pameran arkeologi. Melibatkan siswa dalam proses analisis juga dapat dilakukan dengan bers dilakukan dengan bersama melakukan reka ulang fragmen gerabah atau melibatkan dalam proses katalogisasi temuan. Pemutaran film dokumenter arkeologi kiranya juga menjadi wahana belajar yang menyenangkan jika dikemas bersama proses diskusi.

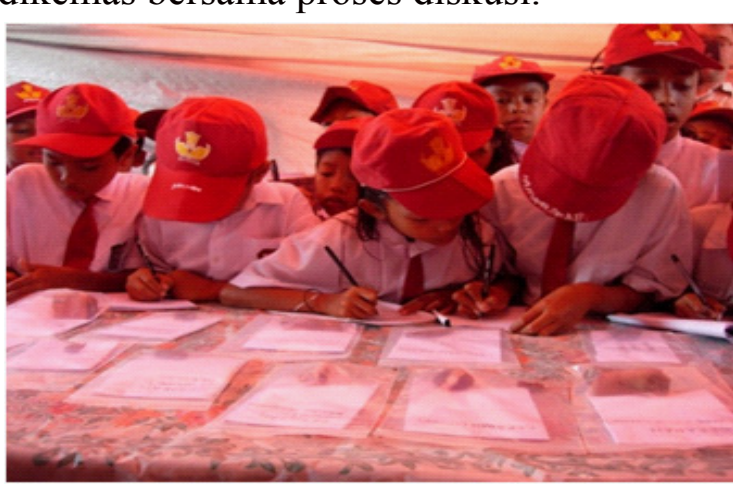

Gambar 3. Siswa SD Mengamati Temuan Hasil Penelitian Arkeologi di Pulau Ay Kepulauan Banda di Lokasi Penelitian Yang Sama Sumber: Dokumen Pribadi)

Ketiga, adalah pengembangan materi. Selama ini materi yang disajikan cenderung sangat konvensional berupa kombinasi antara materi presentasi dan materi cetak. Padaha meninjau transformasi di era informasi in kepekaan siswa terhadap sumber informasi yang interaktif dan dinamis semakin tinggi. Kemasan infornasidengang lebih multimedia perlu disajikan. Aplikasi-aplikasi digital kreatif dapat menjadi solusi. Termasuk pembuatan materi dalam bentuk filmfilm dokumenter pendek. Opsi ini kiranya membuka peluang untuk bekerja sama dengan instansi-instansi sejawat di daerah.

Keempat, adalah peningkatan frekuensi sosialisasi. Hingga tahun 2012 ini jumlah kegiatan sosialisasi ke sekolah mencapai delapan kali dengan lokus beragam. Permintaan pihak sekolah agar frekuens ditingkatkan kiranya bukan persoalan sebatas membalik telapak tangan. Terutama terkai pengelolaan jadwal penelitian lapangan yang sedemikian padat. Solusi untuk ini barangka arkeolog sebagai pengajar tamu yang bersifat informal pada mata pelajaran yang memiliki tautan dengan pengetahuan arkeologi di Maluku.

Kelima, adalah pembinaan tenaga pengajar dengan proses tukar informasi. Dalam konteks ini kemudahan referensi terkait pengetahuan sejarah lokal dapat diberikan kepada para tenaga pendidik. Diskusi bersama sebagai ajang bertukar pikiran juga perlu dikembangkan. Demikian halnya dengan melibatkan guru-guru dengan mata pelajaran yang paling berkaitan dengan tema sejarah budaya untuk hadir dalam seminar arkeologi berskala lokal di daerah. Modus-modus ini kiranya merupakan wahana untuk meningkatkan kepekaan tenaga pendidik sebagai ujung tombak utama pengembangan muatan lokal di daerah.

Tentu keberhasilan dari segenap upaya pengembangan mutu kegiatan sosialisasi arkeologi di Maluku ini bisa mencapai hasil maksimal bila ada sinergi penuh antara semua pihak yang terlibat. Baik dinas terkait, sekolah, tenaga pendidik, siswa dan tentu saja kalangan arkeolog. Sinergi ini bisa tercipta bila ada kesamaan pikir antara pihak-pihak di atas dan hanya dapat dicapai melalui komunikasi yang intens satu sama lain. Harapannya tentu satu, bahwa melalui kontribusi arkeologi ini muatan lokal dapat berkembang sebagai wahana pengetahuan setempat untuk mengembangkan kepekaan daerah pada generasi muda sebagai pengambil keputusan di masa mendatang.

\section{PENUTUP}

Pengelolaan keberagaman kiranya menjadi salah satu kata kunci dalam penyelenggaraan negara di Indonesia. Karakter bangsa yang begitu multkultur menjadi aspek yang membutuhkan pendekatan tepat untuk merangkul seluruh kepentingan. Termasuk bagi dunia pendidikan dimana ada kebutuhan untuk menyelaraskan materi ada kebutuhan untuk menyelaraskan materi ajar nasional dengan kebutuhan akan tema
lokal yang spesifik. Penerapan muatan lokal dipandang sebagai salah satu solusi ideal untuk menjawab kondisi dimaksud. Utamanya dalam kaitan dengan menyediakan materi terkait pengetahuan budaya setempat bagi peserta didik.

Sejauh ini muatan lokal telah menjadi pendekatan yang cukup berhasil sebagai wahana pengetahuan lokal bagi siswa, mesk derajatnya bervariasi. Ketersediaan bahan ajar dan tenaga pendidik yang memadai senantiasa menjadi kendala. Melibatkan individu dan institusi yang bergiat dalam bidang budaya di daerah sebagai pengajar kiranya dapat menjadi salah satu solusi. Dalam konteks pengetahuan sejarah budaya, arkeologi dapa menjadi bidang yang memberikan kontribusi bagi pengembangan muatan lokal.

Maluku sebagai wilayah dengan karakter yang juga heterogen dihadapkan pada tantangan serupa. Terdapat kesenjangan terkait pengetahuan sejarah budaya nasiona dengan pengetahuan serupa dalam konteks lokal. Sosialisasi arkeologi di sekolah merupakan salah satu solusi untuk mengis kesenjangan dimaksud, dimana pengetahuan sejarah budaya lokal dapat ditautkan dalan konteks luas materi kurikulum sejarah nasional. Dikemas dengan tema archaeology goes to school, kegiatan sosialisasi ini hadir dalam bentuk diskusi tatap muka di sekolah dan kunjungan situs.

Mendapat tanggapan positif dari dunia pendidikan di Maluku, pelaksanaan sosialisa pengetahuan arkeologi sebagai muatan loka ni kiranya masih perlu dikembangkan. Mode pengembangan dapat diarahkan pada lima aspek meliputi: pertama, pengembangan tema konten kedua, inisiasi model sosialisasi yang lebih interaktif ketiga, pembaharuan mater keempat, peningkatan frekuensi kelima, pembinaan tenaga guru. Kelima aspek in tentu saja dapat diperluas sesuai kebutuhan sekolah dan peserta didik. Harapannya tentu saja agar pengembangan pengetahuan arkeologi sebagai muatan lokal ini mampu menjadi wahana bagi perluasan wawasan dan pengenalan warisan budaya di Maluku. Pemahaman ini tentu menjadi landasan bag minat generasi muda dalam turut melestarikan warisan budaya nasional. 


\section{DAFTAR PUSTAKA}

Bjork, Christopher. 2004. Decentralisation In Education, Institutional Culture And Teacher Autonomy In Indonesia in International Review of EducationVol. 50 No.3-4. Springfield.

Cleere, Henry. 1984. World cultural resource management: problems and perspectives in Cleere, Henry. 1984. Approaches to the Archaeological Heritage: A Comparative Study of World Cultural Resource Management System. Cambridge: Cambridge University Press. pp. 128

Jameson Jr, John, H., 2000, Public interpretation, education and outreach: the growing predominance in american archaeology in McManamon, Francis and Hatton, Alf. 2000. Cultural Resource Management in Contemporary Society: Perspective on Managing and Presenting the Past. London: Routledge. pp.288

Kohl, P.L. dan C.Fawcett. 1995. Nationalism, politics, and the practice of Archaeological London : Cambridge University Press.

Lowenthal, D.1981. Conclusion : dilemmas of preservation, dalam D. Lowental dan M. Binney (eds), Our past before us, why do we save it?, London: Tample Smith. Hlm. 213-237

Prasodjo, T. 2002. Arkeologi dan Pemberdayaan Masyarakat Lokal. Buletin Cagar Budaya No 2.

Ririmasse, M. 2005. Jejak dan Prospek Penelitian Arkeologi di Maluku. Dalam Kapata Arkeologi Volume 1 No. 1. Ambon: Balai Arkeologi Ambon. pp. 35-55

Ririmasse, M. 2008. Visualisasi tema perahu dalam rekayasa situs arkeologi di Maluku. Dalam Naditira Widya Volume 2 No. 1. Banjarmasin: Balai Arkeologi Banjarmasin. pp. 142-157

Ririmasse, M. 2010. Arkeologi Pulau-Pulau Terdepan di Maluku: Sebuah Tinjauan Awal. Kapata Arkeologi Vol. 6 No. 10. Ambon: Balai Arkeologi Ambon. pp. 71-89
Ririmasse, M. 2011. Arkeologi Kawasan Tapal Batas: Koneksitas Kepulauan Maluku dan Papua. Papua. Vol 3. No. 1. Jayapura: Balai Arkeologi Jayapura pp. 23-38.

Schofield, John. 2007. Heritage management, theory and practice in Fairclough, $G$ (et.al). The Heritage Reader. London: Routledge. pp. 25

Sedyawati, Edy. 2007a. Strategi kebudayaan dalam Kaitan dengan Beberapa Pokok Permasalahan Budaya dalam KeIndonesiaan dalam Budaya: Buku 1 Kebutuhan Membangun Bangsa yang Kuat. Jakarta: Wedatama Widya Sastra.

Sedyawati, Edy. 2007. Jati Diri Budaya dan Pendidikan Formal dalam KeIndonesiaan dalam Budaya: Buku 1 Kebutuhan Membangun Bangsa yang Kuat. Jakarta: Wedatama Widya Sastra.

Tanudirjo, D.A. (1996). Arkeologi pascamodernisme untuk direnungkan. Makalah disampaikan dalam pertemuan Ilmiah Arkelogi VII di Cipanas, 1996

Tanudirjo, D.A. (2003). Warisan Budaya Untuk Semua: Arah Kebijakan Pengelola Warisan Budaya Indonesia di Masa Mendatang. Makalah disampaikan pada Kongres Kebudayaan V, Bukittinggi, 2003 